\title{
PEMANFAATAN KULIT BUAH NAGA MENJADI PERMEN JELLY KERING
}

\author{
Ni Komang Nilawati, Made Suriani, Risa Panti. \\ Jurusan Pendidikan Kesejahteraan Keluarga \\ Universitas Pendidikan Ganesha \\ Singaraja, Indonesia \\ e-mail : nilachaldiesh@gmail.com ,made.suriani@undiksha.ac.id, \\ risa.panti@undiksha.ac.id,
}

\begin{abstract}
Abstrak
Penelitian eksperimen ini bertujuan untuk mengetahui kualitas permen jelly kering kulit buah naga dilihat dari (1) aspek rasa,(2) tekstur (3) warna. Penelitian ini menggunakan panelis terlatih yang terdiri dari 25 orang panelis, Metode pengumpulan data yang digunakan dalam penelitian ini yaitu metode observasi dengan menggunaka instrumen berupa lembar uji organoleptik dengan 3 tingkatan yaitu baik,cukup,dan kurang. Data dianalissis dengan menggunakan tehnik deskritif kuantitatif. Hasil penelitia ini menunjukan kualitas permen jelly kulit buah naga dilihat dari aspek rasa berada dalam kategori baik, dengan skor 2,44, ditinjau dari aspek tekstur berada pada kategori baik dengan skor 2,61 , ditinjau dari aspek warna berada dalam kategori baik dengan skor 2,71. Berdasarkan hasil penelitian ini dapat disimpulkan bahwa limbah kulit buah naga dapat dimanfaatkan menjadi produk olahan permen.
\end{abstract}

Kata kunci : kulit buah naga, kualitas permen jelly.

This experimental study aims to find out the quality of dried jelly candy dragon fruit skin viewed from (1) aspect of taste (2) textures (3) colour. This study used trained panelists consisting of 25 panelists. The method of data collection used in this study was the observation method using instruments the from of organoleptic test sheets with 3 levels good, sufficient and less. Data were analyzed using descriptive quantitative techniques. The results of this study shows the quality of dragon fruit skin jelly candy seen from the aspect of taste in the good . category, with score of 2,44, in terms of the texture aspect in the good category with a score of 2,61, in terms of color aspects in the good category with a score of 2,71 based on the result of this study it can be concluded that dragon fruit skin waste can be used as processed candy products.

Keywords: Dragon fruit, quality, jelly candy.

\section{PENDAHULUAN}

Bali merupakan daerah yang memiliki berbagai macam keunikan diantaranya berupa hasil pertanian yang beraneka ragam, seperti buahbuahan,sayur-sayuran dan tanaman pangan yang dapat memenuhi kebutuhan masyarakat sehari-hari. Salah satunya di Kabupaten Buleleng yang terletak paling utara bali secara geografis yang memiliki wilayah pertanian, terutama pertanian lahan kering selain padi Buleleng juga dikenal luas sebagai penghasil produk holtikultural seperti mangga, anggur, buah naga, berbagai jenis palawija dan umbiumbian. Khususnya di Desa Kubutambahan memiliki penghasilan buah naga yang berlimpah. Buah naga akhirakhir ini namanya semakin populer di Indonesia. Buah yang terbilang unik ini memiliki bentuk bulat lonjong, kulitnya berwarna merah atau kuning, mengkilap, bersirip, juga memiliki cita rasa yang nikmat dan berkhasiat bagi kesehatan sehingga diminati oleh banyak kalangan. 
Saat ini buah naga banyak dijumpai di supermarket, swalayan atau toko buah dan dijual dalam keadaan segar dengan harga yang bervariasi sesuai dengan ukuran, kualitas, dan jenisnya.

Buah naga kulit merah daging putih (Hylocereus undatus), kulit merah daging merah (Hylocereus polyhiruz), dan kulit buah naga merah daging merah super (Hylocereus costaricensis). Buah yang berasal dari tanaman jenis kaktus ini awalnya hanya dijadikan sebagai tanaman hias. Kini tanaman ini telah banyak dibudidayakan sebagai tanaman pertanian yang menghasilkan komoditas unggulan dan permintaanya pun meningkat dari tahun ketahun.

Pada awalnya tanaman buah naga ini dikenal sebagai tanaman hias, hal ini disebabkan batangnya dianggap unik karena bentuknya segitiga dengan duri pendek, bunganya berbentuk corong yang mekar senja hari dan mekar penuh saat tengah malam hari. Lama-kelamaan tanaman buah naga dikenal tidak hanya sebagai tanaman hias melainkan juga menghasilkan buah yang menarik dan enak dimakan sehingga digemari oleh masyarakat dan mulai dikembangkan secara komersial.

Sekilas rasa buah naga seperti buah kiwi, kombinasi antara manis, asam dan segar. Dibalik rasanya yang mais dan menyegarkan, buah naga kaya akan kandugan gizinya. Secara keseluruhan, buah ini baik untuk kesehatan dan dapat memenuhi kebutuhan tubuh akan zat gizi sehari-hari seperti, karbohidrat, serat, vitamin $C$, zat besi, protein dan kalsium (Budiana, 2013:52). Bahan pangan yang kini mulai bayak diminati konsumen tidak hanya memiliki komposisi bahan yag baik, namun pemanfaatan kulit buah yang tidak terpakai dapat juga diolah menjadi sebuah masakan yang memiliki cita rasa yang menarik, tetapi juga memiliki kandungan gizi yang cukup baik bagi tubuh.

Kulit buah naga dapat bermanfaat dalam produksi pangan maupun industri seperti pewarna alami pada makanan dan minuman. Selain itu dalam indusrti, kulit buah naga dapat dijadikan bahan dasar pembuatan kosmetik. Dalam bidang farmakologi kulit buah naga dapat dijadikan sebagai obat herbal alami yang dapat bermanfaat sebagai antioksidan (Cahyono, B. 2009).

Tabel 1. Kandungan Kulit Buah Naga Merah

\begin{tabular}{llll}
\hline No & \multicolumn{1}{c}{ Jenis Analisis } & Satuan & Hasil Analisis \\
\hline 1 & Kadar Air & $(\%)$ & 76,7954 \\
\hline 2 & Kadar Protein & $(\%)$ & 2,0983 \\
\hline 3 & Total Gula & $(\%)$ & 1,1037 \\
\hline 4 & Vit C & $(\mathrm{mg} / 100 \mathrm{~g})$ & 13,9406 \\
\hline 5 & Kadar Antioksidan & (ppmGAEAC) & 76,8290 \\
\hline 6 & Kadar Antosianin & (mg/100g) & 30,0580 \\
\hline \multicolumn{4}{l}{ Sumber: (Surya, Fak. Teknologi Pertanian Unit LayananLab.UNUD.2014) }
\end{tabular}

Pengolahan kulit buah naga ini ditunjukan untuk memanfaatkan kulit buah naga yang selama ini hanya dianggap sebagai limbah, serta untuk menunjukan bahwa limbah tersebut banyak mengandung manfaat bagi kesehatan tubuh (Cahyono, 2009). Limbah kulit buah naga diperoleh dari penjual juice buah di Kawasan Singaraja. Penjual juice ini bertempat di jalan Ayani Singaraja. Kulit buah naga biasanya hanya dibuang dan belum dimanfaatkan secara optimal.
Sehingga peneliti tertarik untuk memanfaatkan kulit buah naga sebagai produk olahan permen jelly kering

Jelly merupakan salah satu bentuk pangan olahan yang banyak diminati oleh masyarakat. Jelly buah adalah cairan sari buah yang diawetkan dengan gula,agaragar dan gelatin. Tujuan pemberian gula dengan kadar yang tinggi pada jelly buah, selain untuk memberikan rasa manis, juga untuk mencegah tumbuhnya mikrobia. Ada 2 macam bentuk olahan jelly, yaitu jelly basah dan jelly kering. Jelly basah diperoleh setelah penirisan buah dari 
larutan gula, sedangkan jelly kering diperoleh dari jelly basah yang dilanjutkan dengan proses pengeringan.

Produk jelly dari kulit buah naga ini dapat ditunjukan untuk semua kalangan, karena selain untuk anak-anak, jelly tersebut dapat dimanfaatkan oleh orang dewasa dan orang tua karena produk tersebut berperan sebagai pangan fungsional dengan kandungan antioksidan yang terdapat pada kulit buah naga dapat menghambat radikal bebas pada tubuh. Penelitian yang dilakukan adalah untuk mencoba memanfaatkan kulit buah naga merah menjadi jelly kering.

Produk jelly darikulit buah naga ini merupakan produk diversifikasi pangan fungsional yaitu pangan dengan nilai gizi yang baik serta banyak kandungan bermanfaat bagi tubuh. Kulit buah naga memiliki kandungan serat dan bervitamin yang baik bagi kesehatan. Selama ini kulit buah naga belum dimanfaatkan secara optimal dan hanya menjadi limbah organik. Untuk itu peneliti ingin memanfaatkan kulit buah naga menjadi suatu produk yaitu berupa produk olahan jelly kering.

Sebagai upaya pemanfaatan limbah kulit buah naga merah, maka pengolahan lebih lanjut diperlukan untuk meningkatkan penganekaragaman olahan jelly dari kulit buah naga merah serta daya gunanya bagi masyarakat untuk memanfaatkan kulit buah naga sebagai olahan kuliner dengan menggunakan bahan baku kulit buah naga.

Peneliti mencoba untuk mengadakan penelitian mengenai pembuatan jelly kering kulit buah naga dengan menggunakan resep sari buah naga sebagai acuan karena memiliki kesamaan memiliki karakteristik serat dan warna, namun kulit buah naga merah masih belum banyak dimanfaatkan secara optimal bila ditinjau dari kandungan serat,warna dan vitamin yang tinggi kulit buah naga dapat diolah menjadi permen jelly.Produk yang akan dibuat pada penelitian ini adalah permen jelly kering kulit buah naga merah.

Adapun hasil peneitian yang relevan dengan penelitian ini adalah penelitian Ni Putu Widya Arsani (2015) yang berjudul Pemanfaatan Kulit Buah Naga Merah Menjadi Selai dengan hasil kualitas selai kulit buah naga merah dari aspek rasa berada dalam kategori baik dengan memperoleh rata-rata sebanyak 2,83. Dari aspek warna berada dalam kategori baik dengan memperoleh ratarata 3. Dari aspek tekstur berada dalam kategori baik dega memperoleh rata-rata 2,79 daan dari aspek konsistensi berada dalam kategori baik yaitu kental dengan memperoleh rata-rata 2,83.

Penelitian Indra Sopiani (2015) yang berjudul Studi Eksperimen Pemanfaatan Kulit Buah Naga Menjadi Sirup dengan hasil kualitas pembuatan sirup kulit buah naga super merah dilihat dari aspek rasa berada dalam kategori baik dengan memperoleh rata-rata sebanyak 2,8. Dari aspek warna berada dalam kategori baik dengan memperoleh rata-rata sebanyak 2,8. Dari aspek aroma berada dalam kategori baik dengan memperoleh rata-rata 2,36.

Penelitian Jumri Yusmarini (2015) yang berjudul Mutu Permen Jelly Buah Naga Merah (Hylocereuspolyrhizus) dengan Penambahan Karagenan dan GUM Arab dengan hasil penelitian menunjukkan bahwa keregenan dan gum arab berpengaruh nyata $(p<0,05)$ terhadap tingkat kesukaan panelis terhadap permen jelly.

Penelitian Dedy insani (2017) yang berjudul Pemanfaatan Labu Kuning dalam Pembuatan Permen Jelly dengan Penambahan Rumput Laut. Adapun hasil penelitian menunjukkan penilaian sensoris memiliki deskriptif warna kuning kecokelatan, agak beraroma labu kuning, tekstur kenyal, berasa labu kuning dan rumput laut dan permen jelly secara umum dapat diterima secara keseluruhan suka. Permen jelly yang dihasilkan dari labu kuning dan rumput laut secara keseluruhan memenuhi standar SNI 35742008 kecuali kadar air melebihi SNI 35742008.

Penelitian Kurnia Afifah (2017) yang berjudul Studi Pembuatan Permen Jelly Dengan Variasi Konsetrasi Sari Kulit Buah Naga dan Ekstrak Angkak. Adapun hasil penelitian menunjukan penambaha variasi konsentrasi sari kulit buah naga 
memberikan pengaruh nyata terhadap parameter kekerasan,pH, kadar air, aktivitas antioksidan angka lempeng total. Angka kapang khamir,dan tekstur, sedangkan penambahan ekstrak angkak memberikan pengaruh nyata pada parameter yaitu $\mathrm{pH}$, kadar air, aktivitas antioksidan. angka kapang khamir dan angka lempeng total. Kedua faktor memberikan interaksi terhadap para-meter $\mathrm{pH}$, kadar air, angka kapang khamir, angka lempeng total dan rasa. Perlakuan kulit buah naga 30\% dan ekstrak angkak $2 \%$ merupakan perlakuan terbaik dengan rerata nilai kekerasan $98,0 \mathrm{~mm} / 50 \mathrm{gr} / 5 \mathrm{dt}$; $\mathrm{pH}$ 4,49; kadar air 19,42\%; gula reduksi 14,64\%; aktivitas antioksidan 5,97\%; angka lempeng total hari ke-60 50,33×102; angka kapang khamir hari ke 60 80,33×102; rasa 3,6; warna 3; aroma 3,1 ; dan tekstur 3,6 .

\section{METODE}

Penelitian ini dilaksanakan di laboratorium Tata Boga pendidikan Kesejahteraan Keluarga Universitas Pendidikan Ganesha. Metode yang digunakan dalam penelitian ini adalah metode observasi dengan menggunakan uji kualitas yang dilihat dari aspek rasa,tekstur dan warna, pengumpuan data dalam penelitian ini dilakukan tiga tempat diantaranya SMK Negeri 2 Singaraja, SMK Triatmajaya Singaraja, dan di jurusan Pendidikan Kesejahteraan Keluarga Universitas Pendidikan Ganesha yang dilaksanakan selama 6 bulan.

Rancangan penelitian adalah strategi yang digunakan untuk mengatur latar (setting) penelitian agar peneliti memperoleh data yang tepat (valid) sesuai dengan karakteristik variabel dan tujuan penelitian.

Bahan yang digunakan dalam pembuatan permen jelly kering kulit buah naga yang terdiri dari (1) Kulit buah naga 200 gr, (2) Gula pasir 250 gr, (3) Air 750 ml, (4) Gelatin 5 gr, (5) Agar-agar tanpa rasa $7 \mathrm{gr}$, (6) Gula halus $100 \mathrm{gr}$ sebagai taburan.

Gula terdapat dalam berbagai bentuk, yakni sukrosa, glukosa,fruktosa dan dektrosa. Dalam pembuatan jelly gula yang digunakan adalah sukrosa yang sehari-hari dikenal sebagai gula pasir. Tujuan penambahan gula dalam pembuatan jelly adalah untuk memperoleh rasa manis yang ideal. Selain itu gula dapat pula berfungsi sebagai pengawet. (Dewa, 2008:64)

Gelatin adalah zat kimia padat, tembus cahaya, tak berwarna, rapuh (jika kering), dan tak berasa, yang didapatkan dari kolagen yang berasal dari berbagai produk sampingan hewan. Gelatin umumnya digunakan sebagai zat pembuat gel pada makanan, farmasi, fotografi, dan pabrik kosmetik. Gelatin merupakan campuran antara peptida dengan protein yang diperoleh dari hidrolisiskolagenyang secara alami terdapat pada tulang atau kulitbinatang. Gelatin komersial biasanya diperoleh dari ikan, sapi, dan kambing. Dalam industri pangan, gelatin dipakai sebagai salah satu bahan baku dari permen lunak, jelly, es krim.

Gelatin merupakan suatu senyawa protein yang diesktraksi dari hewan, dapat diperoleh dari jaringan kolagen hewan yang terdapat pada kulit, tulang dan jaringan ikat. Gelatin yang adaa di pasaran umumnya diproduksi dari kulit dan tulang sapi atau ikan. Gelatin banyak digunakan dalam industri farmasi, kosmetika, fotografi, dan makanan. Penggunaan gelatin dalam produk murni bersifat sebagai penjernih. (Fatimah, 1995).

Agar-agar, agar atau agarosa adalah zat yang biasanya berupa gel yang diolah dari rumput laut atau alga. Di Jepang dikenal dengan nama kanten dan oleh orang Sunda disebut lengkong. Jenis rumput laut yang biasa diolah untuk keperluan ini adalah Eucheuma spinosum (Rhodophycophyta). Beberapa jenis rumput laut dari golongan Phaeophycophyta (Gracilaria dan Gelidium) juga dapat dipakai sebagai sumber agar-agar. Agar-agar sebenarnya adalah karbohidrat dengan berat molekul tinggi yang mengisi dinding sel rumput laut. la tergolong kelompok pektin dan merupakan suatu polimer yang tersusun dari monomer galaktosa.

Gel terbentuk karena pada saat dipanaskan di air, molekul agar-agar dan air bergerak bebas. Ketika didinginkan, 
molekul-molekul agar-agar mulai saling merapat, memadat dan membentuk jaringjaring yang mengurung molekul-molekul air, sehingga terbentuk sistem koloid padat-cair. Jaring-jaring ini dimanfaatkan dalam elektroforesis gel agarosa untuk menghambat pergerakan molekul objek akibat perbedaan tegangan antara dua kutub.

Air memiliki fungsi cukup penting, salah satunya mengangkut zat-zat gizi, termasuk diantaranya vitamin yang larut dalam air dan beberapa mineral yang diperlukan tubuh. Selain itu, fungsi air yang tak kalah penting adalah mengatur suhu tubuh (Ali, 2014)

Meskipun sering diabaikan, air merupakan salah satu unsur penting dalam makanan karena air dapat mempengaruhi penampakan, tekstur, tingkat kerenyahan produk serta cita rasa makanan. Air berfungsi sebagai media reaksi untuk membantu proses pelumatan dari kulit buah naga, dan melarutkan bahan campuran lainnya dalam pembuatan permen jelly kulit buahnaga.

Gula halus adalah bahan masakan berbahan gula berbentuk tepung. Gula halus terbuat dari tanaman tebu. Selain tebu, gula halus juga bisa terbuat dari gula sintetis. Umumnya, gula berbentuk kristal, namun gula halus dibuat dalam bentuk kristal yang lebih kecil. Gula halus berwarna putih bersih dan memiliki rasa manis seperti gula biasa.

Proses pembuatan permen jelly kering kulit buah naga terdiri dari (1) Bersihkan kulit buah naga dan potong kecil-kecil kemudian haluskan dengan blender, (2) Tambahkan gula pasir, agaragar, gelatin kemudian aduk rata. (3) Ambil panci kecil masak pure kulit buah naga bersama dengan campuran gula pasir, agar-agar, gelatin dan masak sampai mendidih, (4) Siapkan loyang persegi tuang adonan yang sudah matang ke loyang, tunggu sampai dingin, (5) Cetak adonan permen jelly kering sesuai seera, (6) Jemur permen jelly kering kulit buah naga dibawah sinar matahari 1-3 hari tergantung kadar air pada permen jelly kering, (7) Kemudian kemas permen jelly kering kulit buah naga untuk menjaga kualitas dari permen jelly kering.
Subjek pada penelitian menggunakan panelis terlatih dengan mengambil sampel sebanyak 25 panelis yang berasal dari guru SMK Negeri 2 Singaraja, SMK Triatma jaya Singaraja, Dosen Jurusan Pendidikan Kesejahteraan Keluarga

Variabel dalam penelitian ini adalah kualitas jelly kering kulit buah naga dilihat dari aspek rasa, warna dan tekstur. Kualitas merupakan tingkat baik buruknya sesuatu yang dapat dinilai dari kesesuaian terhadap persyaratan produk. Kualitas jelly kering kulit buah naga dinilai dari beberapa faktor diantaranya yaitu rasa, warna dan tekstur. Rasa merupakan hasil respon terhadap produk yang nilai melalui indera pencicip, rasa dari jelly kering kulit buah naga manis. Warna merupakan hasil dari pengelihatan mata, warna dari jelly kering kulit buah naga ini adalah merah. Tekstur merupakan hasil dari suatu produk yang dapat dinilai dari meraba permukaannya baik itu kasar, keras, lembut dan halus. Tekstur dari permen jelly kering kulit buah naga ini adalah kenyal.

Metode yang digunakan dalam penelitian ini adalah metode observasi. Metode observasi adalah cara mengumpulkan data dengan melakukan pengamatan secara langsung terhadap objek yang diteliti menggunakan seluruh alat indera (Arikunto, 2002). Observasi digunakan untuk mengumpulkan data tentang kualitas jelly kering kulit buah naga ditinjau dari aspek rasa, warna dan tekstur. Untuk uji kualitas dari jelly kering kulit buah naga ini digunakan uji organoleptif yang meliputi rasa, warna dan tekstur .Penilain organoleptif digunakan untuk meneliti mutu komoditif makanan. Uji organoletif disebut sebagai penilaian yang dilakukan dengan indera manusia atau sensorik.

Uji organoleptik yang digunkan dalam penelitian ini adalah uji mutu hedonik. Dalam uji mutu hedonik ini panelis diminta tanggapan pribadinya tentang kesan baik buruknya hasil penelitian dan menemukan tingkat mutu suatu yang disebut mutu skala hedonik.

$$
\text { Panelis yang terpilih dalam }
$$$$
\text { penelitian ini adalah panelis terlatih. }
$$ 
Jurnal Bosaparis: Pendidikan Kesejahteraan Keluarga

Volume 10, Nomor 2, Juli 2019

Panelis terlatih ini berjumlah 15-25 orang yang biasanya diambil dari personal laboratorium tetapi dapat pula karyawan atau pengawai lain (Soekarto, 1985). Panelis menanggapi dengan cara memberikan tanda chek list $(\sqrt{ })$ sesuai dengan kriteria yang telah ditentukan pada lembar observasi panelis terhadap

kualitas jelly kering kulit buah naga yang berdasarkan tes skala mutu hedonik, data penilaian dapat ditransformasikan dalam skala numerik dan selanjutnya dapat dianalisis statistik untuk interprestasinya. skala mutu hedonik dalam penelitian ini menggunakan rentangan.

Tabel 2. Skala Mutu Hedonik dan Skala Mutu Numerik

Uji Kualitas Permen Jelly Kering Kulit Buah Naga

\begin{tabular}{cc}
\hline Skala Hedonik & Skala Numerik \\
\hline Baik & 3 \\
\hline Sedang & 2 \\
\hline Buruk & 1 \\
\hline
\end{tabular}

(sumber: Soekarto, 1985)

Instrumen yang digunakan dalam penelitian ini berupa lembar uji kualitas yang nantinya akan diberikan pada setiap panelis untuk menilai kualitas jelly kering kulit buah naga yang disajikan. Untuk mendapatkan hasil dan responden maka dibuat tolak ukur dan lembar uji kualitas sebagai berikut :

Tabel 3. Tolak Ukur Permen Jelly Kering Kulit Buah Naga

\begin{tabular}{cccc}
\hline Nilai & Rasa & Tekstur & Warna \\
\hline 3 & Manis & Kenyal & Coklat muda \\
\hline 2 & Kurang manis & Kurang kenyal & Coklat kemerahan \\
\hline 1 & Tidak manis & Tidak kenyal & Coklat \\
\hline
\end{tabular}

Teknik analisis data pada penelitian ini adalah untuk mengetahui proses pembuatan permen jelly kering dilihat dari aspek rasa, bentuk dan warna, Sesuai dengan tujuan penelitian, maka analisis relevan untuk tujuan penelitian tersebut adalah metode analisis deskripif dan kuantitatif. Analisis yaitu penggolahan data dengan cara menyusun secara sistematis dalam bentuk angka-angka atau persentase (Arikunto, 2014).

Setelah dilakukan analisis data dengan menggunakan metode deskriptif kuantitatif terhadap data yang di uji kualitas permen jelly kering, maka akan didapatkan suatu kesimpulan pada kualitas permen jelly kering kulit buah naga yang dilihat dari aspek rasa, tekstur dan warna. Sesuai dengan kriteria yang digunakan baik, cukup dan kurang.

Berikut adalah rumus yang digunakan dalam proses analisis data terhadap kualitas tepung kara kratok sebagai berikut :

Mean $(\mathrm{M})=\sum \mathrm{X}$
$\mathrm{N}$

(Sumber: Koyan, 2012).

Keterangan :

$\mathrm{M}=$ Mean ( rata-rata)

$\Sigma x=$ Jumlah masing-masing skor ( rasa, tekstur dan warna)

$\mathrm{N} \quad=$ Jumlah (sampel).

Rumus pedoman dengan skala 3 (tiga) :

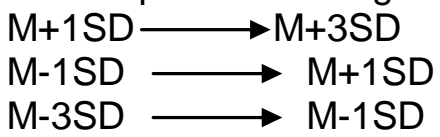

Keterangan Rumus : 
Jurnal Bosaparis: Pendidikan Kesejahteraan Keluarga

Volume 10, Nomor 2, Juli 2019

$\mathrm{M} \quad=$ Mean ( rata tengah)

$\mathrm{SD}=$ Standar Deviasi

Keterangan :

$\mathrm{M}=$ Mean atau rata-rata dicari dengan rumus:

$\mathrm{M}=\frac{1}{2} \mathrm{x}($ Skor Maksimun - Skor Minimum $)$

$\mathrm{SD}=$ Standar Deviasi dicari dengan rumus :

$\mathrm{SD}=\frac{1}{6} \mathrm{x}($ Skor Maksimum - Skor Minimum $)$

Skor Maksimum = 3

Skor Minimum = 1

Berdasarkan rumus diatas, untuk mencari konversi data yang telah terkumpul sehingga memperoleh hasil adalah dengan cara sebagai berikut:

$M=\frac{1}{2} \times($ Skor Maksimun - Skor Minimum)

$\mathrm{M}=\frac{1}{2} \times(3-1)$

$M=2$

$\mathrm{SD}=\frac{1}{6} \mathrm{x}($ Skor Maksimum - Skor Minimum $)$

$\mathrm{SD}=\frac{1}{6} \times(3-1)$

$\mathrm{SD}=0,3$

Acuan pengambilan keputusan yang digunakan untuk menentukan kualitas jelly kering kulit buah naga ini dari aspek rasa, dan tekstur berdasarkan rumus pedoman konversi dengan skala 3 (tiga) adalah sebagai berikut:

$$
\begin{array}{ll}
2,4-3 & =\text { Baik } \\
1,8-2,3 & =\text { Cukup } \\
1,1-1,7 & =\text { Kurang }
\end{array}
$$

\section{PEMBAHASAN}

Hasil dari peneliti ini adalah permen jelly kering kulit buah naga yang diuji kualitas dari aspek rasa,tekstur dan warna, panelis yang digunakan dalam penelitian ini adalah panelis terlatih yang berjumlah 25 orang sesuai teori yang telah dijabarka pada bab III panelis yang digunakan adalah panelis terlatih yang berjumlah 15-25 orang yang diambil dari personal laboratorium tetapi dapat juga karyawan atau pegawai lain (Soekarto,1985), panelis yang digunakan terdiri dari guru SMK N 2 Singaraja guru SMK Triatmajaya Singaraja dan dosen Tata Boga Pendidikan Kesejahteraan Keluarga. Data yang diperoleh dari penelitian ini dianalisis menggunakan analisis deskritif kuantitatif.

Permen jelly kering kulit buah naga yang telah diuji kualitas dari aspek rasa, tekstur dan warna merupakan hasil eksperimen yang mengacu pada resep stadar proses pembuatan jelly buah naga yang telah ditetapkan setelah melakukan eksperimen uji coba pendahuluan yang telah dilakukan pada bab III. adapun tahap pembuatan permen jelly kering kulit buah naga terdiri dari tiga tahap yaitu, tahap persiapan bahan, tahap persiapan alat, dan tahap pelaksanaan.

Hasil uji panelis terhadap kualitas permen jelly kering kulit buah naga dapat dilihat dapat di lihat melalui perhitungan data berikut Kualitas Permen Jelly Kering Kulit Buah Naga

1. Kualitas rasa permen jelly kering kulit buah naga

$$
\begin{aligned}
M & =\frac{\sum X}{N} \\
& =\frac{66}{25} \\
& =2,64
\end{aligned}
$$

2. Kualitas tekstur permen jelly kering kulit buah naga

$$
\begin{aligned}
M & =\frac{\sum X}{N} \\
& =\frac{61}{25} \\
& =2,44
\end{aligned}
$$

3. Kualitas warna permen jelly kering kulit buah naga

$$
\begin{aligned}
M & =\frac{\sum X}{N} \\
& =\frac{71}{25} \\
& =2,84
\end{aligned}
$$


Jurnal Bosaparis: Pendidikan Kesejahteraan Keluarga

Volume 10, Nomor 2, Juli 2019

Tabel 5. Hasil Uji Kualitas Permen Jelly Kering Kulit Buah Naga

\begin{tabular}{ccc}
\hline Aspek yang dilihat & \multicolumn{2}{c}{ Permen jelly kulit buah naga } \\
\hline & Skor & Kategori \\
\hline Rasa & 2,64 & Baik \\
\hline Tekstur & 2,44 & Baik \\
\hline Warna & 2,84 & Baik \\
\hline
\end{tabular}

Dari data diatas diperoleh hasil dari uji panelis terhadap permen jelly kering kulit buah naga menyatakan, kualitas permen jelly kering kulit buah naga yang dinilai dari aspek rasa, tekstur, dan warna memperoleh skor 2,64 yang berada pada kategori baik sesuai dengan tolak ukur yaitu memiliki kriteria rasa.

yang manis, tekstur permen jelly kering kulit buah naga memperoleh skor 2,44 yang berada pada kategori baik sesuai dengan tolak ukur yaitu memiliki kriteria tekstur yang kenyal, warna permen jelly

kering kulit buah naga memperoleh skor 2,84 yang berada pada kategori baik sesuai dengan tolak ukur yaitu memiliki warna coklat muda.

Berdasarkan hasil uji kualitas permen jelly kering kulit buah naga yang dilihat dari aspek rasa,tekstur dan warna dapat dilihat pada diagram batang dibawah ini.

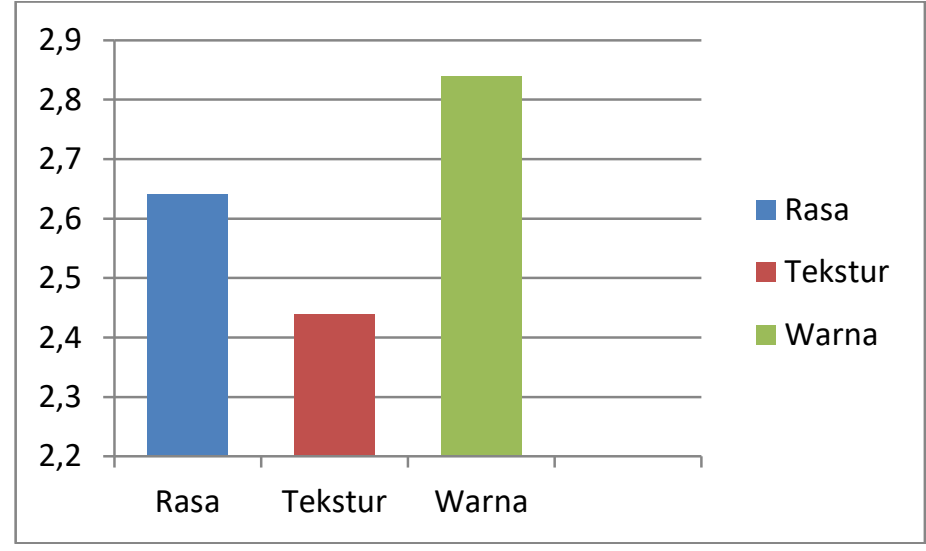

Diagram batang 01 . Hasil uji kualitas permen jelly kering kulit buah naga

Kualitas permen jelly kering kulit Buah naga dari aspek rasa, berdasarkan hasil Uji Panelis dari 25 orang panelis, 16 orang panelis memberi nilai 3 dan 9 orang panelis memberi nilai 2 pada permen jelly kering kulit buah naga dan nilai yang di dapat yakni 2,64 permen jelly kering kulit buah naga ini termasuk dalam kategori baik karena sesuai dengan tolak ukur yang telah ditentukan yaitu permen jelly kulit buah naga memiliki rasa yang manis.

Rasa merupakan tanggapan indra terhadap rangsangan saraf seperti manis,pahit,masam terhadap indra pengecap. Untuk menentukan rasa pada makanan tersebut cara yang digunakan dengan cara mencicipi sehingga dapat merasakan rasa dari masakan tersebut. 
Adapun kritik dan saran dari beberapa panelis pada uji kualitas permen jelly kering kulit buah naga yang dilihat dari aspek rasa yaitu kurangnya rasa khas kulit buah naga pada permen jelly kering kulit buah naga. Kurangnya rasa kulit buah naga dalam permen jelly kering kulit buah naga yang dikarenakan rasa kulit buah naga yang sedikit hambar.

Kualitas permen jelly kering kulit buah naga dari aspek tekstur, hasil yang di proleh dari uji kualitas permen jelly kkering kulit buah naga menggunakan 25 Orang panelis, 11 orang panelis memberikan nilai 3 dan 14 orang panelis memberikan nilai 2 pada permen jelly kering kulit buah naga yang mendapatkan nilai 2,44 yang berada pada kategori baik. Permen jelly kering kulit buah naga sesuai dengan tolak ukur. Dan sesuai dengan kualitas tekstur yang baik sesuai dengan keadaan makanan yang seharusnya, sedangkan tekstur yang buruk adalah tekstur tidak sesuai dengan yang dikehendaki seperti kembali ke tekstur yang semula dan permen jelly kering kulit buah naga sudah sesuai dengan tekstur yangdiharapkan.

Dalam proses pembuatan permen jelly kering kulit buah naga melakukan proses penjemuran yang dilakukan dengan sinar matahari secara langsungdalam waktu 2 hari atau sampai cairan pada permen jelly kering kulit buah naga menghilang. dan tekstur kenyal pada permen jelly kering kulit buah naga didapat dari bahan yang digunakan seperti agar-agar, karena bahan agar-agar dan gelatin merupakan bahan dasar dalam pembuatan jelly dan memiliki tekstur yang kenyal jika dicampurkan pada bahan makanantertentu.

Adapun masukan dari beberapa panelis terhadap kualitas permen jelly kering kulit buah naga yang dilihat dari aspek tekstur adalah tekstur dari permen jelly kering kulit buah aga kurang kenyal karena terlalu kering.

Kualitas permen jelly kering kulit buah naga dari aspek warna pada suatu hidangan memiliki peranan yang sangat penting karena dengan penampilan warna yang menarik seseorang aka tertarik untuk mengkonsumsi dan sekaligus dapat membangkitkan selera makan. Dari hasil uji kualitas permen jelly kering kulit buah naga ditinjau dari aspek warna diperoleh rata-rata 2,84 termasuk dalam kategori baik dan sesuai dengan kriteria yang diharapkan yaitu coklat muda, warna coklat muda diperoleh dari proses pembuatan permen jelly kering yang melalui proses perebusan, proses karamelisasi dan proses penjemuran.

\section{SIMPULAN}

1. Pembuatan permen jelly kering kulit buah naga dibuat dengan cara pemilihan bahan-bahan yang bagus dengan melalui proses: pencucian, penghalusan, perebusan, pendinginan, pencetakan, pengeringan dan pengemasan.

2. Berdasarkan analisis data yang telah didapatkan dari panelis terlatih dapat disimpulkan uji kualitas permen jelly kering kulit buah naga dilihat dari aspek rasa yaitu memiliki rasa manis pada permen jelly dan pada aspek teksturpermen jelly kering kulit buah naga memiliki tekstur yang kenyal dan pada aspek warna permen jelly kering kulit buah naga memiliki warna coklat muda, warna coklat muda yang didapat dari permen jelly karena adanya proses karamelisasi dan proses penjemuran pada permen jelly. Dari semua aspek yang diproleh dari uji kualitas permen jelly kering kulit buah naga, sudah sesuai dengan tolok ukur yang diharapkan.

\section{SARAN}

1. Kulit buah naga bisa dimanfaatkan menjadi prodak olahan yang sangat bermanfaat karena kulit buah naga memiliki manfaat fungsional dan memiliki serat yang tinggi.

2. Untuk penelitian selanjutnya, agar memperoleh hasil yang maksimal atau lebih awet proses penjemuran pada permen jelly kering bisa dilakukan lebih lama.

3. Untuk peneliti selanjutnya, untuk menghasilkan produk permen 
Jurnal Bosaparis: Pendidikan Kesejahteraan Keluarga

Volume 10, Nomor 2, Juli 2019

jelly perlu penambahan gula dan diuji coba lagi untuk mendapatkan tekstur yang lebih kenyal dengan bentuk yang rapi dan tidak mengkerut. Untuk warna dapat ditambahkan pewarna makanan guna mendapatkan warna yang menarik.

\section{DAFTAR RUJUKAN}

Afifah, Kurnia. 2017. Studi Pembuatan Jelly Dengan Variasi Konsentrasi Sari Kulit Buah Naga Dan Ekstrak Angkak. Volume 11 Nomor 2, November 2017.

Ali.2014. Master Jus Alami Buah \& Sayuran. Jakarta: PT. Buku Kita

Anggadiredja, T. Jana. (2009). Rumput Laut ; Pembudidayaan, Pengolahan, \&Pemasaran Komoditas Perikanan Potensial. Depok : Penebar Swadaya.

Arikunto, Suharsimi. 2002. Prosedur Penelitian Suatu Pendekatan Praktek. Jakarta: PT Rineka Cipta.

Arikunto, Suharsimi. 2014. Dasar-Dasar Evaluasi Pendidikan (edisi 2). Jakarta: Bumi Aksara

Arsani, Ni Putu Widya. 2015. "Pemanfaatan Kulit Buah Naga Merah Menjadi Selai". E-Journal Bosaparis Undiksha. Volume 3, No $1 . \quad$ Tersedia pada (http://ejournal.undiksha.ac.id/inde x.php/JJPKK/article/view/5972)

Budiana, N S.2013. Buah Ajaib Tumpas Penyakit. Jakarta : Penebar Swadaya

Cahyono. J B \& Suhajo B.(2009). Hepatitis

A. Edisi 1. Yogyakarta: Kanisius

Jumri,

Yusmarini.

2015. "MutuPermenJelliBuah Naga Merah (hillocerreuspolyhirus) DenganPenambahanKeragenan Dan Gum Arab". Jom FAPERTA Universitas Riau Vol.2No.1. Tersedia pada(http://ejournal.undiksha.ac.id/ index.pview/5972).

Koswara, Sutrisna. (2009). Cara Sederhana Membuat Jam dan Jelly.

Koyan, Wayan. 2012. Statistik Pendidikan Teknik Analisia Data Kuantitatif. Singaraja: Universitas Pendidikan Ganesha.

Kristanto. 2003. Buah Naga: Pembudidayaan di Pot dan di Kebun. Jakarta: Penebar Swadaya

Kristanto. Daniel.2008. Berkebun Buah Naga. Jakarta: penebar swadaya

Soekarto, S.T. 1985. Penilian Organoleptik. Jakarta: Bhatara Karya Aksara.

Sopiani, Indra.2015. "Studi Eksperimen Pemanfaatan Buah Naga Menjadi Sirup". E-Journal Bosaparis Undiksha. Volume 3, No 1. Tersedia pada (http://ejourrnal.undiksha.ac.id.inde x.php/JJPKK/artikel/view/4760). 